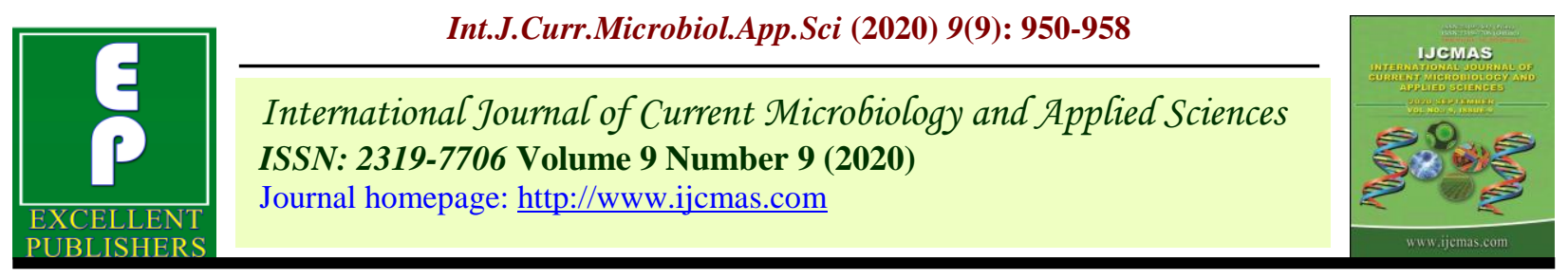

Original Research Article

https://doi.org/10.20546/ijcmas.2020.909.117

\title{
Evaluation of Early Growth and Morphological Variation in Casuarina Hybrid Clones
}

\author{
M. Hussnain*, V. Maheswarappa, Ramakrishna Hegde, Ganapati and M. Jadeyegowda \\ College of Forestry, Ponnampet, Kodagu- 571216, Karnataka, India \\ *Corresponding author
}

Keywords

Casuarina hybrid clones, Casuarina equisetifolia

Article Info

Accepted:

10 August 2020

Available Online:

10 September 2020

\begin{abstract}
A B S T R A C T
Casuarinas are among the most important tree species for the production of high yielding wood biomass for fibre, rayon and energy needs. Among the 96 species of trees and shrubs in the family Casuarinaceae, Casuarina equisetifolia has gained much attention due to its multiple end-uses. India is the largest Casuarina growing country in the world, with an estimated 800,000 ha of plantations. About 500,000 ha are planted with Casuarina in the coastal states of Andhra Pradesh, Orissa, Tamil Nadu and the Union Territory of Puducherry. In order to assess early growth of casuarina hybrid clones for agroforestry, an experiment was conducted at MAHRS, Iruvakki, Shivamogga, Karnataka. Eight casuarina hybrid clones were planted in row-column design with 3 replication and $3 \times 2 \mathrm{~m}$ spacing. The observations on height (ht) and collar diameter (CD) were recorded up to 9 months. Stem form (axis persistence and stem straightness), branching habit (thickness and length) were assessed by scoring. There was significant difference in quantitative and qualitative parameters observed for eight casuarinas hybrid clones. Considerable height was recorded in $\mathrm{CH} 2, \mathrm{CH} 4$ and $\mathrm{CH} 5(2.68 \mathrm{~m}, 2.72 \mathrm{~m}$, and $2.67 \mathrm{~m}$ respectively) at nine months after planting. These clones have also performed better in qualitative parameters compared to clones CJ9 \& HPF as these were not suitable for high rainfall areas.
\end{abstract}

\section{Introduction}

Forests in India have played a significant role in meeting the domestic and industrial wood requirements, before the enactment of the Forest Conservation Act, 1980 and National Forest Policy (1988). India is one of the major consumer of wood and its products in the Asia-Pacific region, estimated wood of 152 million $\mathrm{m}^{3}$ in the country would need by 2020 (FAO, 2009). The world's agricultural lands occupied $4889 \mathrm{~m}$ ha, an increase of 7\% (311 $\mathrm{m}$ ha) since 1970 (FAO, 2013), whereas agricultural land area has decreased by $53 \mathrm{~m}$ ha since 2000 (Knickel, 1990). Increasing wood demand coupled with changes in the land-use pattern, have necessitated significant interest towards agroforestry, a land-use system which is being practised across the country in various forms (Christersson, 2005).

Clonal forestry has a significant contribution in industries like paper, packaging, tissue, paperboard, plywood, veneer, etc., which use wood as a raw material. Industrial agroforestry plantations with the fast-growing 
tree species such as Poplar, Eucalyptus, Willow, Leucaena, Casuarina, Bamboo and Melia are the ideal that can be grown commercially in private lands.

Casuarinas are widely planted in the tropics, subtropics and Mediterranean countries because of their ready adaptability to a variety of environmental conditions and also for their rapid growth performance.

The potential of multipurpose tree species in enhancing the diversity, sustainability and productivity of the marginal ecosystem has received increased attention in recent years. In India and many other countries, Casuarinas are planted and harvested at 5 to 10 years rotation. In Casuarina plantations, the organic matter returns to soil in the form of foliage is relatively high.

Casuarinas are excellent soil reformers and increase soil fertility through nitrogen fixation (Dommergues et al., 1990). Its nitrogenfixing ability, desirable stem form, fast growth, and light crown characteristics make it an ideal tree for agroforestry (Saravanan et al., 2012; Viswanath et al., 2001).

Casuarinas are among the most important tree species for the production of high yielding wood biomass for fiber, rayon and energy needs (Hegde, 1993). Among the 96 species of trees and shrubs in the family Casuarinaceae, Casuarina equisetifolia has gained much attention due to its multiple enduses (Turnbull, 1990).

India is the largest Casuarina growing country in the world, with an estimated 800,000 ha of plantations (Pinyopusarerk and Williams, 2000). Nicodemus (2009) estimated that about 500,000 ha area planted with Casuarina in the coastal states of Andhra Pradesh, Orissa, Tamil Nadu, and the Union Territory of Puducherry.
The nitrogen-fixing ability and adaptability to grow in a wide range of soil and climatic conditions, including moisture and nutrientlimited sites, makes Casuarina a preferred choice for commercial and environmental planting program. The short rotation period of 3-4 years suits the average Indian farmer with small landholding (Rawat et al., 2011). The demand for $C$. equisetifolia wood has been increasing dramatically due to its excellent raw material for paper and pulp industries and preferred as poles and scaffoldings for the past 25 years (Kumar et al., 1996).

Versatile casuarina hybrid clones provide new opportunities for improving the productivity of Casuarina plantations through selection and breeding. The excellent coppicing ability makes it amenable for clonal forestry. Clonal plantations raised from casuarina hybrids readily root and quickly establish in plantations as well as in any form of the agroforestry practices after planting. Since Casuarina plantations are raised in short rotations of 3 to 5 years in India, clonal forestry will lead to rapid genetic improvement and increasing wood production.

\section{Materials and Methods}

\section{Planting material}

Planting stock was developed and released by different Institutes and organizations were selected for the present study. Among the eight clones, six hybrid clones (270 ramets) procured from Institute of Forest Genetics and Tree Breeding Coimbatore, one casuarina hybrid clone MTP (45 ramets) from Forest College and Research Institute, Mettupalayam. One casuarina hybrid clone HPF (45 ramets) from Hariharapolyfibre, Harihara Grassim Industry were acquired for planting. The detail specifications of clones are mentioned in Table 1. 


\section{Planting site}

The experiment was conducted at Main Agricultural and Horticultural Research Station Iruvakki, Shivamogga district of Karnataka state $\left(14^{\circ} 02^{\prime} 51.261^{\prime \prime} \mathrm{N}\right.$, latitude; $75^{\circ} 11^{\prime} 56.714 " \mathrm{E}$ longitudes, altitude $670 \mathrm{~m}$ ). Mean annual temperature was $31.1^{\circ} \mathrm{C}$ and mean annual rainfall was $1050 \mathrm{~mm}$ during the year 2019. The soil is dark red, clay loam texture with $\mathrm{pH}$ of 6-7.

\section{Experimental design}

The experiment was laid out in a row-column design (William et al., 2002). There were eight hybrid clones considered as treatment planted in three replications with a spacing of $3 \mathrm{~m} \times 2 \mathrm{~m}$ as 15 ramets per clone for each replication. The experimental area was ploughed prior to the planting in July 2019.

\section{Assessment}

After nine months of planting, each clone were measured for height $(\mathrm{Ht})$, collar diameter (cd). In addition each clone was scored subjectively for four morphological characteristics; axis persistence, stem straightness, branchlet length and thickness. Details of the assessment are given in Table 2.

\section{Data analysis}

The data were analysed by one-way or twoway analysis of variance (ANOVA) using (SPSS- Statistical Package for the Social Sciences). Prior to statistical analysis, variables were checked for normality and transformed when necessary.

\section{Results and Discussion}

Study revealed the significant difference in growth and morphological characteristics among the casuarina hybrid clones (Fig. 1).
Among the clones $\mathrm{CH} 4$ was superior $(2.72 \mathrm{~m})$ closely followed by $\mathrm{CH} 2(2.68 \mathrm{~m})$ and $\mathrm{CH} 5$ (2.67) for height growth. The clone CJ9 had found to be the significant lower height (1.18 m) among the different clones (Fig. 2). There was a significant difference reported in $\mathrm{CH} 2$ $(1.52 \mathrm{~cm})$ with highest collar diameter among clones. Minimum collar diameter was recorded in CJ9 and HPF $(0.84 \mathrm{~cm})$ (Table 3).

\section{Qualitative parameter}

Among the clones, $\mathrm{CH} 5$ (4.8) and $\mathrm{CH} 2$ (4.3) were on par with almost complete axis persistence. However, CH4 (3.5), MTP (3.3), and HPF (3.2) were statistically on par. Significantly lower axis persistence was observed in CH1 (2.4) and CJ9 (2.5).

The stem form after nine months of planting improved among different clones. The values differed significantly between the clones. $\mathrm{CH} 2$ and $\mathrm{CH} 5$ had higher stem straightness (4.3) among the clones. The clones $\mathrm{CH} 4$, MTP and CJ9 were almost straight with one or two small bends. However, the lower stem straightness was observed in CH1 (2.4) (Table $3)$.

Analysis of data demonstrates that after nine months of planting, branching habits of different clones improved significantly. Among the clones, $\mathrm{CH} 2$ and $\mathrm{CH} 5$ had better branch thickness with score (3.1). Clones $\mathrm{CH} 1, \mathrm{CH} 3$, and $\mathrm{CH} 4$, were statistically on par with an average score. However, MTP, CJ9 and HPF had a lower form of branch thickness after nine months.

The branch length improved for most of the clones, among the clones HPF, MTP, CJ9, and $\mathrm{CH} 4$ were on par with shorter branch length. Clones $\mathrm{CH} 1, \mathrm{CH} 3$, and $\mathrm{CH} 5$, were on par with moderate branch length. The lower scoring was recorded in $\mathrm{CH} 2$ (1.6). 
The maximum production can be achieved by obtaining a combination of high survival and high productivity per plant. Clones in the study exhibited higher survival rate $(94.00$ $\%$ ), which were planted in the month of July 2019. The higher survival rate of hybrid clones was attributed to rooting capacity, sprouting, abiotic environment and planting density (Ceulemans and Deraedt, 1999). In the present study, the interspecific clones of C. equisetifolia and $C$. Junghuhniana have performed better than intraspecific clones which are comparable to their study. Earlier studies with the interspecific hybrid families exhibit them holding a desirable combination of parental characters like early adventitious rooting and resistance to blister bark disease apart from fast growth (Kannan et al., 2014; Nicodemus et al., 2013).

The higher increase in collar diameter is due to clonal adaptability to high rainfall area and interspecific hybrid, which is coping with environmental factors and genetic characters of the selected parents. However, CJ9 and HPF were not suited to high rainfall areas. Padhy et al., (2014) studied variation in early growth among seed sources and clone of Casuarina in North coastal Andhra Pradesh. Assessment of one year's growth showed a significant difference between the four accessions. DBH values recorded for Casuarina clones ranged from $1.3 \mathrm{~cm}-4.5 \mathrm{~cm}$ which is comparable to the present study.

Table.1 Clonal details of hybrids with taxonomy and its pedigree

\begin{tabular}{|c|c|c|c|}
\hline SI. No. & Clone ID & Taxa & Pedigree \\
\hline 1 & CH1 & $\begin{array}{l}\text { Interspecific hybrid } \\
\text { C. equisetifolia } \mathrm{x} C \text {. } \\
\text { junghuhniana }\end{array}$ & $\begin{array}{l}\text { Selection from fullsib family produced by } \\
\text { control pollination between first- } \\
\text { generation parent clones }\end{array}$ \\
\hline 2 & $\mathrm{CH} 2$ & $\begin{array}{l}\text { Interspecific hybrid } \\
\text { C. equisetifolia } \mathrm{x} C \text {. } \\
\quad \text { junghuhniana }\end{array}$ & $\begin{array}{l}\text { Selection from fullsib family produced by } \\
\text { control pollination between first- } \\
\text { generation parent clones }\end{array}$ \\
\hline 3 & $\mathrm{CH} 3$ & $\begin{array}{l}\text { Interspecific hybrid } \\
\text { C. junghuhniana } \mathrm{x} C \text {. } \\
\text { equisetifolia }\end{array}$ & $\begin{array}{l}\text { Selection from fullsib family produced by } \\
\text { control pollination between first- } \\
\text { generation parent clones }\end{array}$ \\
\hline 4 & $\mathrm{CH} 4$ & $\begin{array}{l}\text { Interspecific hybrid } \\
\text { C. equisetifolia } \mathrm{x} C \text {. } \\
\quad \text { junghuhniana }\end{array}$ & $\begin{array}{l}\text { Selection from fullsib family produced by } \\
\text { control pollination between first- } \\
\text { generation parent clones }\end{array}$ \\
\hline 5 & CH5 & $\begin{array}{l}\text { Interspecific hybrid } \\
\text { C. equisetifolia } \mathrm{x} C \text {. } \\
\quad \text { junghuhniana }\end{array}$ & $\begin{array}{l}\text { Selection from fullsib family produced by } \\
\text { control pollination between first- } \\
\text { generation parent clones }\end{array}$ \\
\hline 6 & MTP & $\begin{array}{l}\text { Interspecific hybrid } \\
\text { C. equisetifolia } x \text { C. } \\
\quad \text { junghuhniana }\end{array}$ & $\begin{array}{l}\text { Selection from fullsib family produced by } \\
\text { control pollination between first- } \\
\text { generation parent clones }\end{array}$ \\
\hline 7 & CJ9 & Casuarina junghuhniana & $\begin{array}{l}\text { Selection from half-sib progeny trial (first } \\
\text { generation) }\end{array}$ \\
\hline 8 & $\mathrm{HPF}$ & Casuarina equisetifolia & $\begin{array}{l}\text { Selection from half-sib progeny trial (first } \\
\text { generation) }\end{array}$ \\
\hline
\end{tabular}


Table.2 Characteristic assessed on each Casuarina hybrid clone for growth and morphological parameters

\begin{tabular}{|c|c|c|}
\hline Characteristic & Unit & Explanation \\
\hline \multicolumn{3}{|l|}{ Quantitative trait } \\
\hline Height (Ht) & $\mathrm{m}$ & From ground level to the apex of the leading shoot \\
\hline Collar diameter $(\mathbf{C d})$ & $\mathrm{cm}$ & Collar region, i.e. $5 \mathrm{~cm}$ above the soil surface \\
\hline \multicolumn{3}{|l|}{ Qualitative trait } \\
\hline Axis persistence & $0-5$ & $\begin{array}{l}0=\text { Axis loses persistence at } 25 \% \text { of the total height. } \\
1=\text { Axis loses persistence at } 50 \% \text { but }>25 \% \text { of the total height. } \\
2=\text { Axis loses persistence at } 75 \% \text { but }>50 \% \text { of the total height. } \\
3=\text { Axis loses persistence only at }>75 \% \text { of the total height. } \\
5=\text { Axis is completely persistent. }\end{array}$ \\
\hline Stem straightness & $1-5$ & $\begin{array}{l}1=\text { Very crooked with }>2 \text { serious bends. } \\
2=\text { Slightly crooked with }>2 \text { small bends or at least one acute } \\
\text { bend. } \\
3=\text { Almost straight with } 1 \text { or } 2 \text { small bends. } \\
5=\text { Completely straight. }\end{array}$ \\
\hline Branch thickness & $1-5$ & $\begin{array}{l}1=\text { Very heavy, }>3 \text { branches with diameter } 1 / 3 \text { rd of the main } \\
\text { stem. } \\
2=\text { Heavy, } 2 \text { to } 3 \text { branches with diameter } 1 / 3 \text { rd of the main stem. } \\
3=\text { Light, only one branch with diameter } 1 / 3 \text { rd of the main stem. } \\
5=\text { Very light, branch diameter }<1 / 3 \text { rd of the main stem. }\end{array}$ \\
\hline Branch length & $1-3$ & $\begin{array}{l}1=\text { Long }>1 / 4 \text { th of the total height. } \\
3=\text { Short }<1 / 4 \text { th of the total height. }\end{array}$ \\
\hline
\end{tabular}

Table.3 Mean values of growth and morphological characteristics at nine months age of Casuarina hybrid clones

\begin{tabular}{|c|c|c|c|c|c|c|c|}
\hline $\begin{array}{c}\text { Sl. } \\
\text { No. }\end{array}$ & $\begin{array}{c}\text { Clone } \\
\text { name }\end{array}$ & Height & $\begin{array}{c}\text { Collar } \\
\text { diameter }\end{array}$ & $\begin{array}{c}\text { Axis } \\
\text { persistent }\end{array}$ & $\begin{array}{c}\text { Stem } \\
\text { straightness }\end{array}$ & $\begin{array}{c}\text { Branch } \\
\text { thickness }\end{array}$ & $\begin{array}{c}\text { Branch } \\
\text { length }\end{array}$ \\
\hline $\mathbf{1}$ & $\mathrm{CH} 1$ & $2.18^{\mathrm{bc}}$ & $1.48^{\mathrm{c}}$ & $2.4^{\mathrm{a}}$ & $2.4^{\mathrm{a}}$ & $2.4^{\mathrm{ab}}$ & $1.8^{\mathrm{ab}}$ \\
\hline $\mathbf{2}$ & $\mathrm{CH} 2$ & $2.68^{\mathrm{c}}$ & $1.52^{\mathrm{c}}$ & $4.3^{\mathrm{de}}$ & $4.3^{\mathrm{c}}$ & $3.1^{\mathrm{b}}$ & $1.6^{\mathrm{a}}$ \\
\hline $\mathbf{3}$ & $\mathrm{CH} 3$ & $1.81^{\mathrm{ab}}$ & $1.00^{\mathrm{ab}}$ & $2.4^{\mathrm{abc}}$ & $2.8^{\mathrm{ab}}$ & $2.2^{\mathrm{ab}}$ & $1.9^{\mathrm{b}}$ \\
\hline $\mathbf{4}$ & $\mathrm{CH} 4$ & $2.72^{\mathrm{c}}$ & $1.28^{\mathrm{bc}}$ & $3.5^{\mathrm{cd}}$ & $3.5^{\mathrm{bc}}$ & $2.7^{\mathrm{ab}}$ & $2.0^{\mathrm{bc}}$ \\
\hline $\mathbf{5}$ & $\mathrm{CH} 5$ & $2.67^{\mathrm{c}}$ & $1.38^{\mathrm{bc}}$ & $4.8^{\mathrm{e}}$ & $4.3^{\mathrm{c}}$ & $3.1^{\mathrm{b}}$ & $1.8^{\mathrm{ab}}$ \\
\hline $\mathbf{6}$ & $\mathrm{MTP}$ & $1.42^{\mathrm{a}}$ & $0.99^{\mathrm{ab}}$ & $3.3^{\mathrm{bc}}$ & $3.6^{\mathrm{bc}}$ & $1.9^{\mathrm{a}}$ & $2.1^{\mathrm{bc}}$ \\
\hline $\mathbf{7}$ & $\mathrm{CJ} 9$ & $1.18^{\mathrm{a}}$ & $0.84^{\mathrm{a}}$ & $2.5^{\mathrm{ab}}$ & $3.2^{\mathrm{ab}}$ & $2.0^{\mathrm{a}}$ & $2.0^{\mathrm{bc}}$ \\
\hline $\mathbf{8}$ & $\mathrm{HPF}$ & $1.28^{\mathrm{a}}$ & $0.84^{\mathrm{a}}$ & $3.2^{\mathrm{abc}}$ & $2.8^{\mathrm{ab}}$ & $1.9^{\mathrm{a}}$ & $2.3^{\mathrm{c}}$ \\
\hline Mean & & 1.99 & 1.16 & 1.82 & 1.82 & 1.53 & 1.39 \\
\hline $\mathbf{S . E m} \mathbf{\pm}$ & & 0.199 & 0.123 & 0.08 & 0.07 & 0.08 & 0.03 \\
\hline $\mathbf{C D}(\mathbf{0 . 0 5})$ & 0.6 & 0.372 & 0.24 & 0.21 & 0.26 & 0.11 \\
\hline
\end{tabular}

CD- Critical Difference; *: Figures with similar letters as superscript do not differ significantly 
Fig.1 General view of experimental plot after nine months of planting

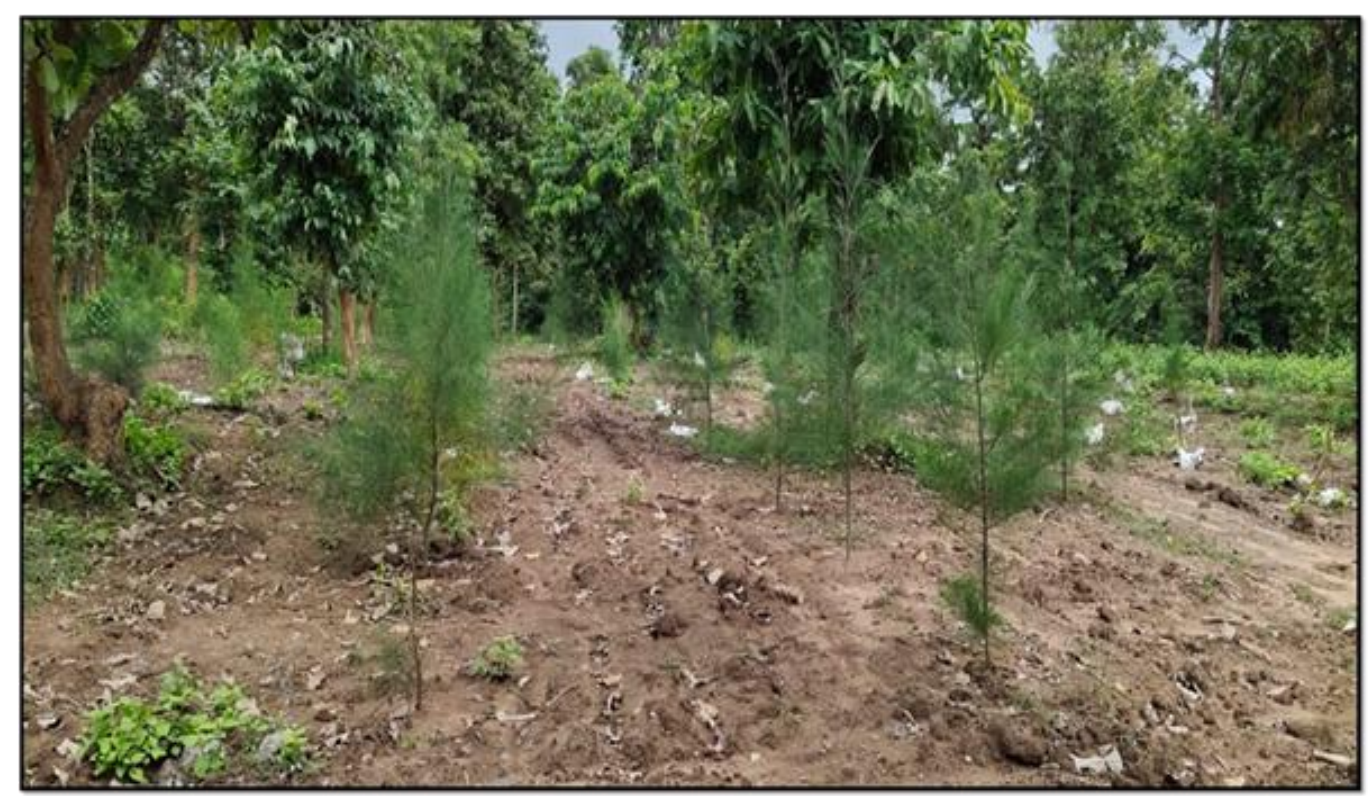

Fig.2 Height of clone after nine months of planting

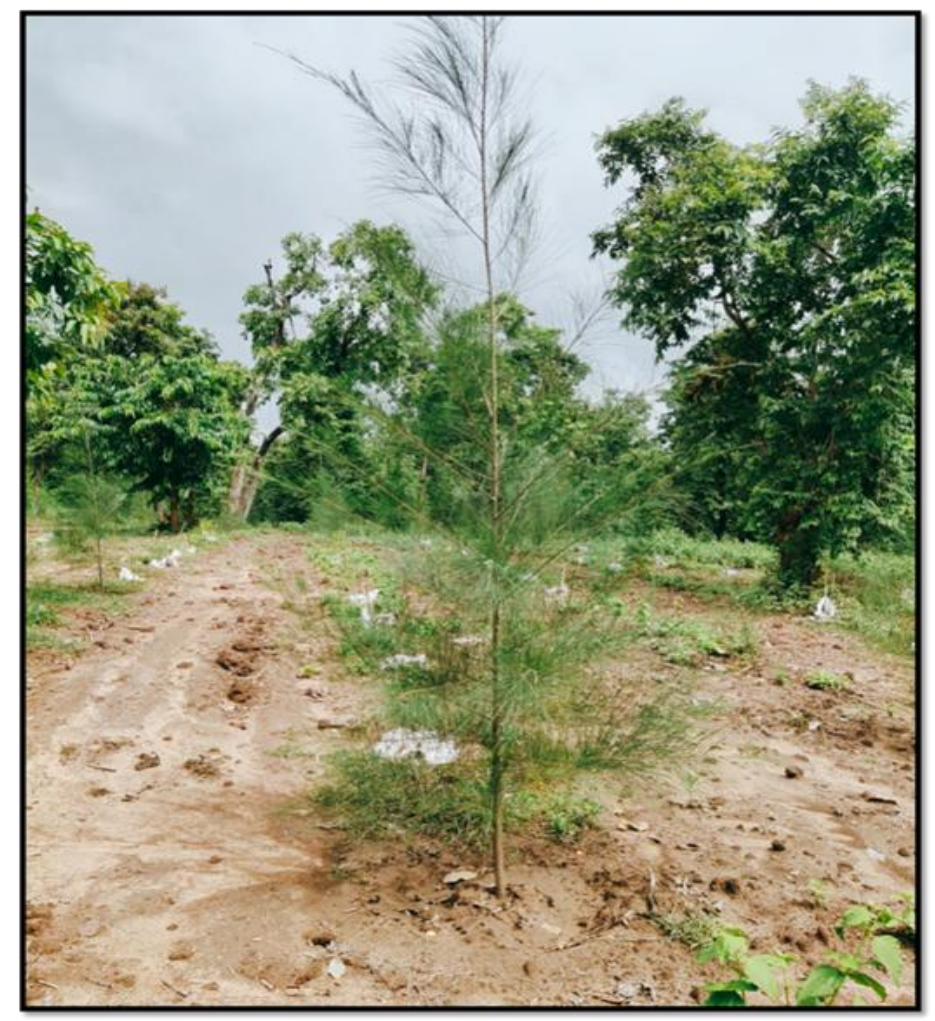

\section{Stem form}

Qualitative parameters like axis persistence, stem form, stem straightness, branch thickness and branch length in casuarina hybrid clones or any of the fast-growing tree species are helpful in selecting the clones for the introduction into agroforestry practices in 
the form of bund planting, alley cropping, shelterbelts and windbreaks.

Axis persistence is the ability of a tree to retain its primary axis. In the present study, the axis persistence of different Casuarina hybrid clones varied significantly. Stem straightness also varied considerably among the clones. Piset et al., (2014) opined that the clonal trial of Casuarina junghuhniana in Thailand showed significant variation in axis persistence and stem straightness despite the vigorous growth. Similar results were in line with Kageyama and Kikuti (1988) who reported in clonal trials of Casuarina hybrid clones had inconsistent for stem form and revealed that genetical and environmental factors also influence on the stem form.

\section{Branching characteristics}

For branching characteristics, branch thickness and branch length were analysed in the present study. Branch thickness differ significantly between clones, although the majority of the clones were found to have thick branches, i.e. diameter greater than $1 / 3^{\text {rd }}$ of the adjacent stem. Similar results were reported by Piset et al., (2014) for different Casuarina junghuhniana clones in Thailand. Branch length was also found to differ considerably among clones with most of the clones having branch length of $1 / 4^{\text {th }}$ of the total height. Longer branch length (1.6) was recorded in $\mathrm{CH} 2$ (Table 3).

More of the branch length was attributed to a clonal character which suited to a particular environment. Casuarina junghuhniana is often planted for windbreaks and as such branching characteristics are critical issue as they influence the stability of trees in windstorms. Dense and fine branches with more horizontal insertion are considered the more suitable structure for windbreaks (Piset et al., 2014).

\section{References}

Ceulemans, R. and Deraedt W., 1999. Production physiology and growth potential of poplars under short-rotation forestry culture. For. Ecol. Manag., 121(1-2):9-23.

Christersson, L., 2005. Plant physiological aspects of woody biomass production for energy purposes. Cited in K.S. Verma, D.K. Khurana and L. Christersson, eds. Short rotation forestry for industrial and rural development. Nauni, Solan, Himachal Pradesh, India, Indian Society of Tree Scientists.

Dommergues, Y. R., Diem, H. G. and Sougoufara, B., 1990.Nitrogen Fixation in Casuarinaceae: Quantification and improvement. In: Advances in Casuarina Research and Utilization. (Eds. M. H. EL-LAKANY, J. W. TURNBULL and J. L. BREWBAKER). Cairo, Egypt. pp. 110-121.

FAO, 2009. India forestry outlook study. Working Paper No. APFSOSII/WP/2009/06. Food and Agricultural Organisation, Ministry of Environment and Forests, Government of India (GoI), 2009.

FAO, 2013. United Nations database; http://faostat.fao.org/.

Hegde, N. G., 1993. Scope for production of industrial raw materials through farmers. In: Proc., ICFRE/FAO/UNDP Workshop on Prod. Gen. Improv. Planting Mater. for Afforestation Programme (eds. K. VIVEKANANDAN, K. N. SUBRAMANIAN, N. Q. ZABALA and K. GURUMURTHI). RAS/91/004, Philippines. Document No. 7. pp. 150164.

Kageyama, P.Y. and Kikuti, P., 1988. Comparison between clones and open- 
pollinated progenies originating from a population of Casuarinas in Brazil. Proc. IUFRO meeting on Breeding Tropical Trees: population structure and genetic improvement strategies in clonal and seedling forestry. Pattaya, Thailand, December 1988, pp. 227-235.

Kannan, K., Nicodemus, A. and Jayaraj, R.S.C., 2014. Clonal variation in the adventitious rooting behaviour of Casuarina equisetifolia, $C$. junghuhniana and their interspecific hybrids. In: Jayaraj, R.S.C., Warrier, R.R., Nicodemus, A., Kumar, N.K. (Eds.). Advances in Casuarina Research in India. Proceedings of $2^{\text {nd }}$ National Seminar on Casuarinas. Institute of Forest Genetics and Tree Breeding, Coimbatore, Tamil Nadu, India. pp. 271-274.

Knickel, K., 1990. Agricultural structural change: impact on the rural environment. J. Rural Sci., 6(4):383393.

Kumar, A., Gurumurthi, K. and Patel, M., 1996. Pulp and paper making properties of 15 clones of Casuarina equisetifolia. IPPTA 8(4):13-17.

Nicodemus, A., 2009. Casuarina - A Guide for Cultivation. Institute of Forest Genetics and Tree Breeding (Indian Council of Forestry Research and Education) Coimbatore, India. pp.16.

Nicodemus, A., Kannan, K., Sagariya, Y.C., Pauldasan, A., Karthikeyan, A. And Singh, B.G., 2013. Variation in blisterbark disease incidence among Casuarina equisetifolia, $C$. junghuhniana and their interspecific hybrids and its implications for disease resistance breeding. In: Balu, A., Jayaraj, R.S.C., Regupathy, A., Mohan, V., Warrier, R.R., Raghunath, T.P., Kumar, N.K. (Eds.). Forest Health Managerment. Proc. of the National Seminar on Forest Health Management.
Institute of Forest Genetics and Tree Breeding, Coimbatore, Tamil Nadu, India. pp. 552-563.

Padhy, S.K., Ramakrishna, T., Mishra, S. and Rao, M.V., 2014. Variation in Early Growth among Seed Sources and Clone of Casuarina Tested in North Coastal Andhra Pradesh, India, Proc. of Fifth Int. Casuarina Workshop. Casuarina improvement for securing rural livelihoods, 3-7, February 2014, Chennai, India, pp.116-117.

Pinyopusarerk, K. and Williams, E.R., 2000. Range-wide provenance variation in growth and morphological characteristics of Casuarina equisetifolia grown in Northern Australia. For. Ecol. Manag., 143:219232.

Piset, L., Luangviriyasaeng, V., Laosakul, S., and Pinyopusarerk, K., 2014. Clone Trial of Casuarina junghuhniana in Thailand, Proc. of Fifth Int. Casuarina Workshop. Casuarina improvement for securing rural livelihoods, 3-7, February 2014, Chennai, India, pp. 8590.

Rawat, G.S., Kumar, N.K. and Nicodemus, A., 2011. Research and development of Casuarinas in India. (Cited in Zhong, C., Pinyopusarerk, K., Kalinganire, A. and Franche, C. (Eds), Improving Smallholder Livelihoods through Improved Casuarina Productivity, Proc. of the 4th Int. Casuarina Workshop, Haikou, China, 21-25 March 2010. China Forestry Publishing House, pp. 11-16.

Saravanan, S., Buvaneswaran, C., Veeramani, T. and Jayaraj, R.S.C., 2012. Casuarina equisetifolia - cotton based agroforestry system in Cauvery delta zone of Tamil Nadu for higher economic returns. (Cited in Jayaraj, R.S.C., Warrier, R.R., Nicodemus, A. and Kumar, N.K. (Eds) Advances in 
Casuarina Research in India, Viswanath, S., Manivachakam, P. and Proceedings of the 2nd National Seminar on Casuarinas, Institute of Forest Genetics and Tree Breeding Coimbatore. pp. 385-390.

Turnbull, J.W., 1990. Taxonomy and genetic variation in Casuarinas. (Cited in ElLakany, M.H., Turnbull, J.W. and Brewbaker, J.L. (Eds), Advances in Casuarina Research and Utilization. (Desert Development Centre AUC, Cairo. pp. 1-11.

George, M., 2001.Casuarina equisetifolia in agroforestry practices, 187-192 (Cited in Gurumurthi, K., Nicodemus, A. and Siddappa (Eds.), Casuarina Improvement and Utilization, Institute of Forest Genetics and Tree Breeding, Coimbatore, India.

William, E.R., Matheson, A.C. and Harwood, C.E., 2002. Experimental design and Analysis for Tree improvement, CSIRO Publishing, Melbourne: 214.

\section{How to cite this article:}

Hussnain, M., V. Maheswarappa, Ramakrishna Hegde, Ganapati and Jadeyegowda, M. 2020. Evaluation of Early Growth and Morphological Variation in Casuarina Hybrid Clones. Int.J.Curr.Microbiol.App.Sci. 9(09): 950-958. doi: https://doi.org/10.20546/ijcmas.2020.909.117 